\title{
Evidence for Host Selectivity and Specialization by Epizoic Chelonibia Barnacles Between Hawksbill and Green Sea Turtles
}

\author{
Liberty L. Boyd ${ }^{1 *}$, John D. Zardus ${ }^{2}$, Courtney M. Knauer ${ }^{1}$ and Lawrence D. Wood ${ }^{3}$ \\ ${ }^{1}$ Department of Biology, Florida International University, Miami, FL, United States, 2 Department of Biology, The Citadel, \\ Charleston, SC, United States, ${ }^{3}$ Florida Hawksbill Project, National Save the Sea Turtle Foundation, Fort Lauderdale, FL, \\ United States
}

\section{OPEN ACCESS}

Edited by:

Sergey Dobretsov,

Sultan Qaboos University, Oman

Reviewed by:

Benny K. K. Chan,

Academia Sinica, Taiwan

Ali Nasrolahi,

Shahid Beheshti University, Iran

${ }^{*}$ Correspondence:

Liberty L. Boyd

Iboyd008@fiu.edu

Specialty section:

This article was submitted to

Coevolution,

a section of the journal

Frontiers in Ecology and Evolution

Received: 01 November 2021

Accepted: 07 December 2021

Published: 24 December 2021

Citation:

Boyd LL, Zardus JD, Knauer CM

and Wood LD (2021) Evidence

for Host Selectivity and Specialization

by Epizoic Chelonibia Barnacles

Between Hawksbill and Green Sea

Turtles. Front. Ecol. Evol. 9:807237.

doi: 10.3389/fevo.2021.807237
Epibionts are organisms that utilize the exterior of other organisms as a living substratum. Many affiliate opportunistically with hosts of different species, but others specialize on particular hosts as obligate associates. We investigated a case of apparent host specificity between two barnacles that are epizoites of sea turtles and illuminate some ecological considerations that may shape their host relationships. The barnacles Chelonibia testudinaria and Chelonibia caretta, though roughly similar in appearance, are separable by distinctions in morphology, genotype, and lifestyle. However, though each is known to colonize both green (Chelonia mydas) and hawksbill (Eretmochelys imbricata) sea turtles, C. testudinaria is $>5$ times more common on greens, while C. caretta is $>300$ times more common on hawksbills. Two competing explanations for this asymmetry in barnacle incidence are either that the species' larvae are spatially segregated in mutually exclusive host-encounter zones or their distributions overlap and the larvae behaviorally select their hosts from a common pool. We indirectly tested the latter by documenting the occurrence of adults of both barnacle species in two locations (SE Florida and Nose Be, Madagascar) where both turtle species co-mingle. For green and hawksbill turtles in both locations (Florida: $n=32$ and $n=275$, respectively; Madagascar: $n=32$ and $n=125$, respectively), we found that $C$. testudinaria occurred on green turtles only (percent occurrence - FL: 38.1\%; MD: 6.3\%), whereas the barnacle C. caretta was exclusively found on hawksbill turtles (FL: 82.2\%; MD: 27.5\%). These results support the hypothesis that the larvae of these barnacles differentially select host species from a shared supply. Physio-biochemical differences in host shell material, conspecific chemical cues, external microbial biofilms, and other surface signals may be salient factors in larval selectivity. Alternatively, barnacle presence may vary by host micro-environment. Dissimilarities in scute structure and shell growth between hawksbill and green turtles may promote critical differences in attachment modes observed between these barnacles. In understanding the co-evolution of barnacles and hosts it is key to consider the ecologies of both hosts and epibionts in interpreting associations of chance, choice, and dependence. Further studies are necessary to investigate the population status and settlement spectrum of barnacles inhabiting sea turtles.

Keywords: turtle barnacle, epibiont, assortative epibiosis, substratum specificity, basibiont preference, carapace, Madagascar, Florida (United States) 


\section{INTRODUCTION}

Barnacles in the family Chelonibiidae (superfamily Coronuloidea) are common epibionts of sea turtles (Zardus, 2021). Their highly mobile hosts provide them with a substratum that protects them from predators (Foster, 1987) while also aiding their dispersal (Rawson et al., 2003) and supporting their reliance on passive feeding (Lane et al., 2021). Chelonibiid barnacles occupy multiple turtle and non-turtle host species (Zardus et al., 2014) but there has been minimal characterization of differences in their ecological niches and settlement preferences, limiting our understanding of the association between barnacles and hosts. While predominantly associating with marine turtles, chelonibiids have also been observed on other aquatic reptiles including the American alligator, diamondback terrapins, and saltwater crocodilians (Monroe and Garrett, 1979; Seigel, 1983; Nifong and Frick, 2011), as well as manatees (Zardus et al., 2014) and various crabs and other arthropods (Ortiz et al., 2004; Cheang et al., 2013; Ewers-Saucedo et al., 2017).

Barnacles in the genus Chelonibia have been evolving as commensals of marine turtles since the late Miocene (Ross, 1963) and several extinct forms illuminate their evolutionary history with diverse hosts (Collareta and Newman, 2020; Collareta et al., 2021). It has recently been recognized that there are but two extant species in the genus, Chelonibia testudinaria and Chelonibia caretta (Cheang et al., 2013; Zardus et al., 2014), both occurring globally on marine turtles. Though sometimes confused for each other, with informed examination they can usually be readily distinguished. Along with several morphological differences between the two (Monroe, 1981) are distinctions in their attachment modes that leave diagnostic marks on their hosts.

Typical of other acorn (balanomorph) barnacles, C. testudinaria (and presumably C. caretta) develops through multiple swimming larval stages in the plankton before being able to find a host and becoming competent to attach and metamorphose (Zardus and Hadfield, 2004). The terminal larval stage, the cyprid, searches for a suitable substratum and attaches by gluing down a pair of organs, the antennules, specialized for surface adhesion though, surprisingly, not obviously specialized for adhering to particular surface types (Dreyer et al., 2020). Subsequent to attaching, metamorphosis follows within hours which involves forming a calcareous shell cemented to the substratum. Most barnacles are immovably fixed in place at this point but $C$. testudinaria's capability for slow movements across the substratum allows it to modify its feeding position throughout life (Chan et al., 2021). Paradoxically, despite its mobility, this species is otherwise extremely passive, exhibiting no active feeding behavior as an adult, probably as a consequence of having evolved to live on mobile hosts (Lane et al., 2021). But how the planktonic larvae of both of these barnacles optimize a rendezvous with sea turtles and identify their itinerant hosts remains enigmatic. Available evidence suggests the two likely meet up along coastlines where larvae can become entrained in harbors, embayments, and lagoons (Sloan et al., 2014; Lim et al., 2021) where juvenile and adult sea turtles forage, as opposed to open-ocean locations.
Habitat characteristics for epibionts of marine turtles potentially vary due to differences in host species' behavior and carapace growth and composition. With the exception of leatherback turtles, sea turtle shells are covered with a varying number of enlarged, keratinous epithelial scales known as "scutes," which are known to provide suitable substratum for attachment of a variety of epibionts (Frazier et al., 1991; Scharer, 2001; Frick et al., 2004). However, differences in both scute development and carapace grooming behavior among sea turtle species may influence the type, placement, and persistence of epibiotic growth found on each. In contrast to green turtle scutes that maintain smooth seams along their edges as they expand, the anterior edge of each hawksbill scute subducts the one in front of it, producing the characteristic "imbrication" of the scutes unique to hawksbill turtles (Palaniappan, 2007). Though very little is known of ecdysis in sea turtles, in contrast to green turtles, hawksbills appear not to shed outer layers of their scutes, which consequently thicken over time, making them famous for their particular and unfortunate suitability in the international tortoiseshell trade (Mrosovsky, 2000; Pederson, 2021).

Hawksbill (Eretmochelys imbricata) and green sea turtles (Chelonia mydas) are globally distributed marine turtles currently listed by the IUCN as "Critically Endangered" and "Endangered," respectively, throughout their ranges (Seminoff, 2004; Mortimer and Donnelly, 2008). Though hawksbills typically prefer coral reef/hard bottom habitats, while green turtles prefer seagrass pastures, the often-close proximity of these habitat types to one another can result in overlapping ranges between the two turtle species (Bjorndal and Bolten, 2010, Wood pers. obs.). Cooccurring populations of green turtles and hawksbills have been documented in the same coastal reef habitats, e.g., south Florida, Turks and Caicos, and Northwestern Indian Ocean (Bourjea et al., 2006; Makowski et al., 2006; Taquet et al., 2006; Wood et al., 2013; Bechhofer and Henderson, 2018). As juveniles and subadults, both hawksbill and green turtles frequently remain in relatively small home ranges for extended periods (10 years+) prior to embarking on reproductive migrations (Berube et al., 2012; Hazel et al., 2013; Wood et al., 2017). The swimming behaviors of adult hawksbills and green turtles are similar, using their foreflippers to propel themselves through the water column and hind flippers for directional movement (Wyneken, 1996). Green turtles are known to actively groom their carapaces with their flippers and/or by rubbing on underwater surfaces, which could strongly influence patterns of epibiotic recruitment (Heithaus et al., 2002, Wood pers. obs.). Symbiosis through mutualistic behaviors exhibited by reef fishes foraging on marine turtle epibionts is another factor that may preclude barnacles from successful settlement (Sazima et al., 2010). Hawksbill individuals have been observed displaying postures that signal fishes to clean their exterior (Grossman et al., 2006) and cleaner fishes have been recorded cleaning the carapace and skin of green turtles as well (Losey et al., 1994; Sazima et al., 2010). Booth and Peters (1972) reported a barnacle removal behavior in moon wrasse, Thalassoma lunare, in which individuals targeted skin barnacles for consumption. Further stomach analysis of moon wrasses confirmed the presence of barnacle material as a dietary item. The active removal of epibiota by green 
turtle self-cleaning behaviors and symbiotic fishes presents major limitations to the settlement success of various epibiota. As Chelonibia barnacles are obligate associates of sea turtles, it is imperative to examine the abundance, distribution, and settlement preferences of these co-evolved symbionts to properly assess their conservation status, particularity in relation to the conservation status of the host sea turtle species. Identifying key host-commensal species relationships is a first step in properly determining turtle barnacle population abundances and distributions.

The objective of the present study was to provide insight into the host preferences of Chelonibia barnacles when access to multiple host species was available in the wild. The overlap of habitat use between hawksbills and green turtle in southeast Florida and Nosy Be, Madagascar provided an opportunity for assessing biases in the presence of C. testudinaria and C. caretta among these two host turtle species. We also related the attachment modes of C. caretta and C. testudinaria (cementation and downcutting, respectively) to what is known of scute growth and host behavior in these two turtle species to explore the possibility that one or both of these barnacles is specialized for a particular host.

\section{MATERIALS AND METHODS}

Between 2007 and 2020, juvenile and subadult green and hawksbill turtles were captured from co-occurring populations in the nearshore waters of SE Florida United States (Palm Beach through Monroe Counties) (Figure 1), and the islands of Nosy Sakatia, Nosy Tanikely, and Nosy Komba, which are part of the Nosy Be Island complex located in the northwest region of Madagascar (Figure 1). In Florida, the hawksbills were encountered in 2-26 $\mathrm{m}$ of water along the Southeast Florida Continental Reef Tract, a relatively high-latitude reef system with varied community structure that includes reef-building Acropora corals in the southern portion (FL Keys), gradually transitioning to algae/sponge/octocoral-dominated habitats near its northern terminus in Palm Beach County (Jaap and Hallock, 1990; Banks et al., 2008). This highly variable, non-uniform seascape is in close proximity to the Florida Current, a branch of the Gulf Stream that

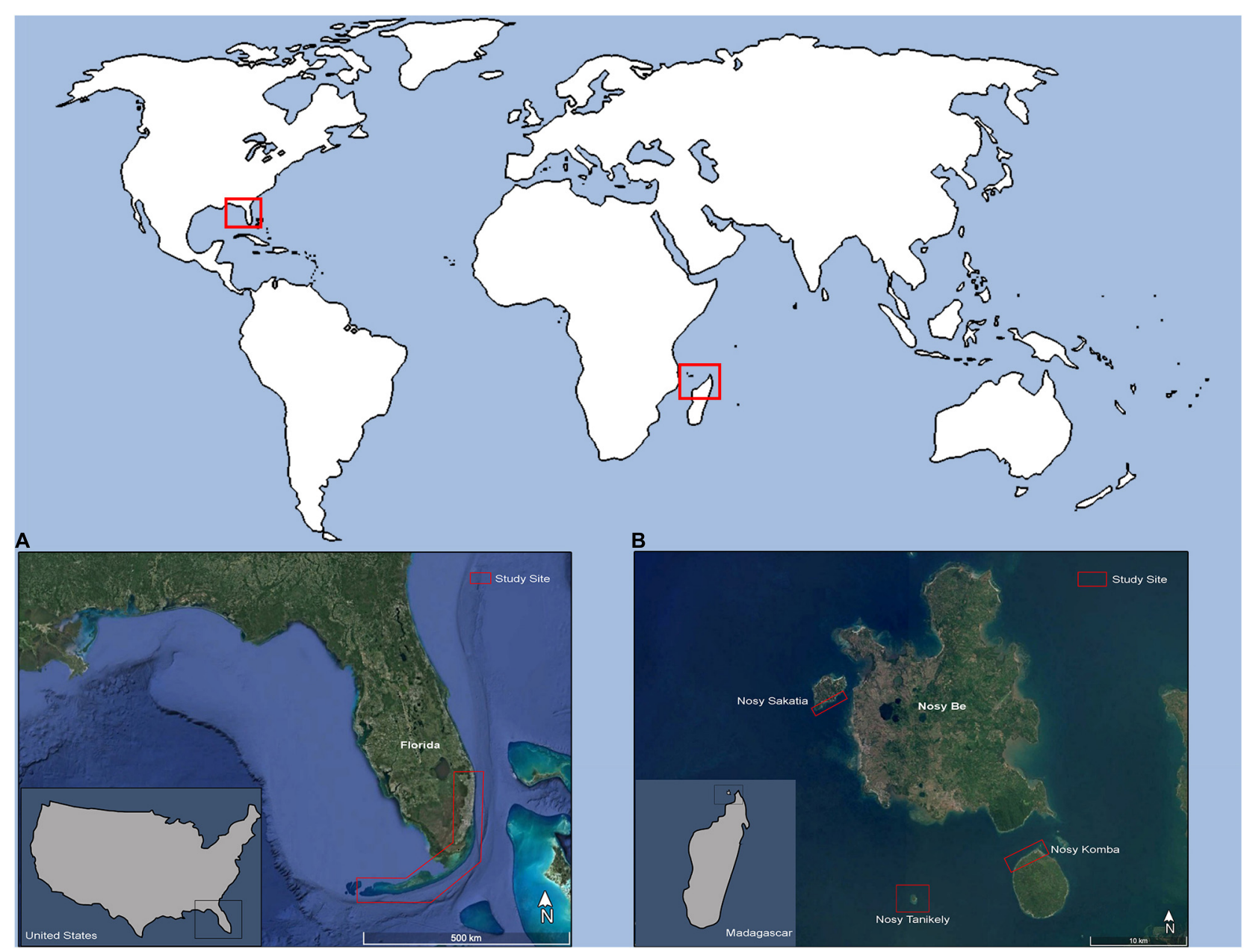

FIGURE 1 | Map of study sites in southeast Florida (A) and Nosy Be, Madagascar (B). 
carries warm tropical water northward along the SE Florida Coast from the Gulf of Mexico and Caribbean. The green turtles were encountered in 1-3 m of water in Palm Beach County Florida at Lake Worth Lagoon (West Palm Beach, FL) and Jupiter Inlet (Jupiter, FL), two well-flushed seagrass-dominated tidal lagoons with open-ocean access via nearby major navigable inlets.

In Madagascar, green turtles were observed at a shallow, seagrass shoal with surrounding fringing reefs on the coast of Nosy Sakatia with a tidal range depth of approximately 0-4 m (McKenna and Allen, 2003). Juvenile and adult male and female green turtles forage and rest at this site (Sagar, 2001). Adult and sub-adult hawksbill turtles were encountered between 2 and $8 \mathrm{~m}$ of water in shallow coastal coral reef systems off the coasts of Nosy Tanikely and Nosy Komba. Fringing reefs in these areas are dominated by Acropora corals; however, live coral coverage has decreased around 20\% since 1998 with significant changes every 4 of 5 years due to isolated coral bleaching events (Webster and McMahon, 2002; McKenna and Allen, 2003; Obura, 2012; Obura et al., 2017). In the northwest of Madagascar predominant currents move in a northward direction toward Mozambique in a counterclockwise direction (McKenna and Allen, 2003). While captured at different locals within the Nosy Be Island complex, sea turtle species were found to co-occur within each island, particularly at Nosy Sakatia and Nosy Komba, most likely due to the nearshore seagrass beds that are more extensive at these two islands (Knauer pers. obs.).
Depending on water depth, turtles were either dip-netted from a boat or hand-captured with the use of snorkel or SCUBA gear, with hand-capture via snorkeling being the only method of capture for Madagascar turtles. Turtles were brought up onto the boat and the incidence of two barnacle species (C. testudinaria and C. caretta) on the carapaces of green and hawksbill turtles were quantified and recorded from photographs taken directly above each subject (Figure 2). Photos were analyzed to enumerate barnacle abundance. Data was analyzed in Excel and RStudio. The abundance of C. caretta on hawksbill carapaces and C. testudinaria on green turtle carapaces between the two study sites were compared using a Welch's two-sample $t$-test $(\alpha=0.05)$.

\section{RESULTS}

Discriminating Chelonibia testudinaria from C. caretta was possible from photographs because in the former, wall sutures widen upward and the parieties become splayed at their tips with radii extended in between; whereas, in the latter species the seams between the parieties remain pressed close together with no radii visible but with alae visibly underlapping the parities at their apex (Figure 3). Chelonibia testudinaria attaches via adhesive cementation of its basal membrane which spreads underneath an even, supporting platform made of numerous

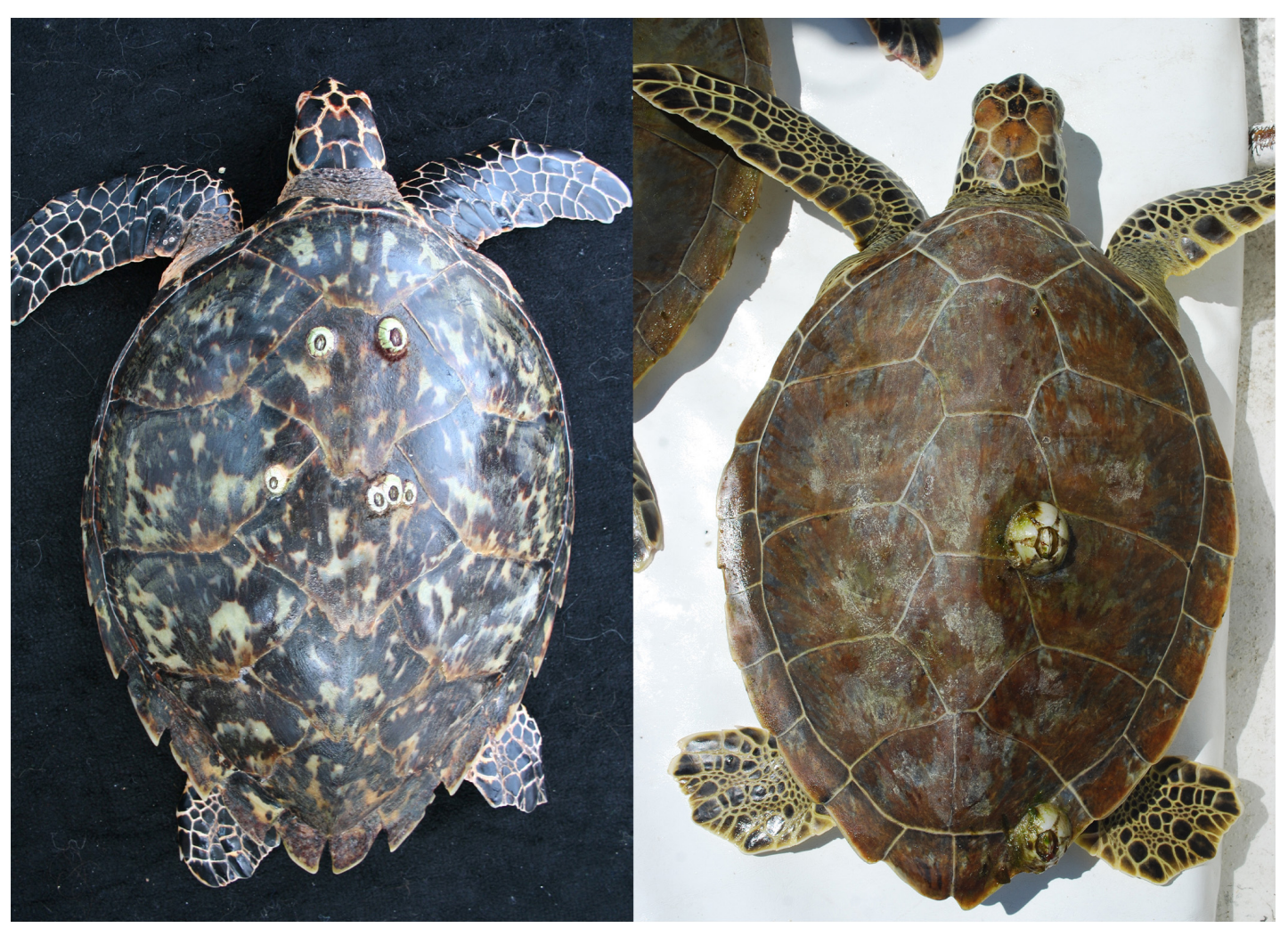

FIGURE 2 | Representative photographs of hawksbill sea turtle (left) and green sea turtle (right) from the present study with presence of barnacle species (C. caretta and C. testudinaria, respectively). 


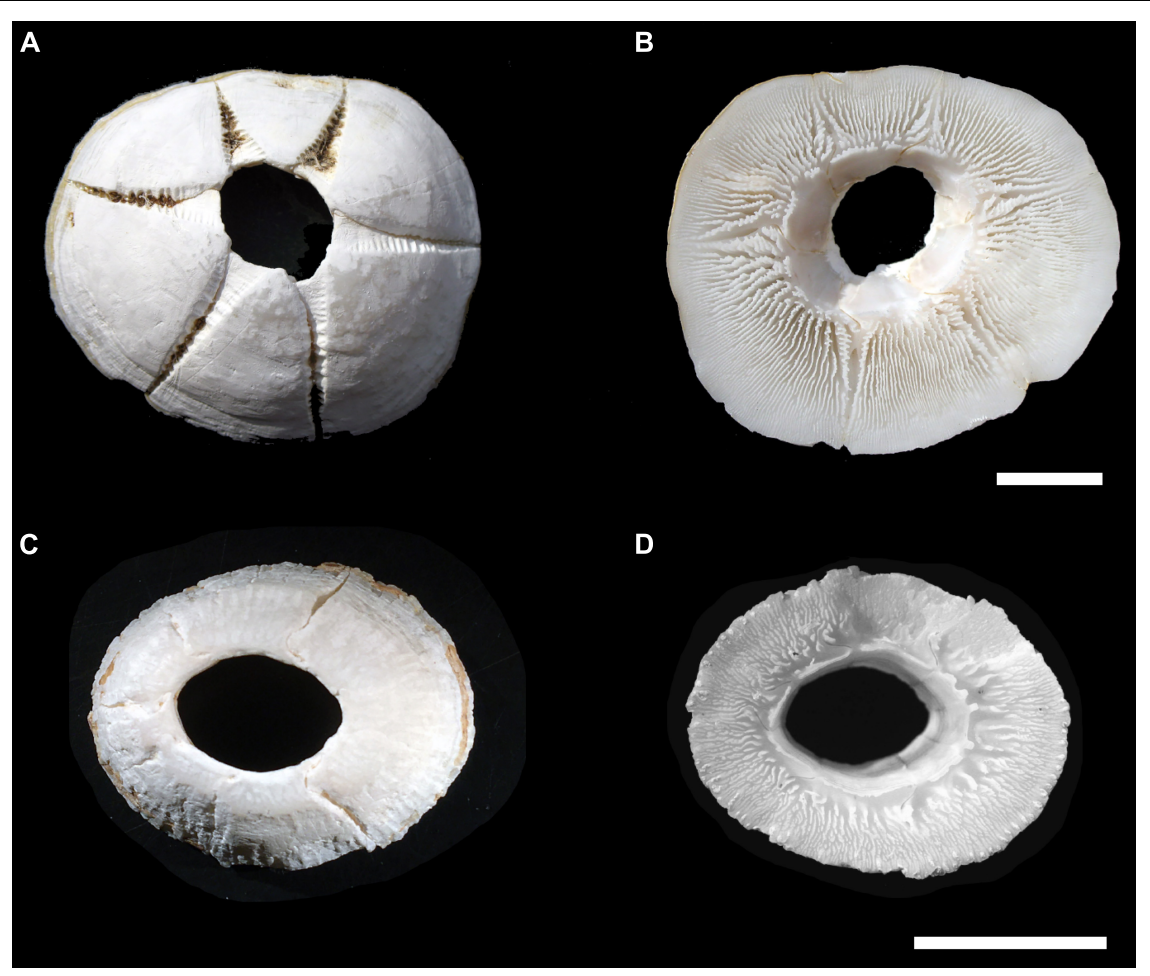

FIGURE 3 | The scute-attaching turtle barnacles: Chelonibia testudinaria collected from a green sea turtle in Japan (specimen courtesy of Hiroyuki Suganuma), apical view (A) and basal view (B); and C. caretta collected from a hawksbill sea turtle in Barbados (specimen courtesy of Marina Fastigi), apical view (C) and basal view (D). Scale bars $=2 \mathrm{~cm}$.

septal wall termini (Figure 3B). Its adhesion is impermanent which, uniquely among barnacles, facilitates slow movement by this species across its substratum (Moriarity et al., 2008; Chan et al., 2021). Chelonibia caretta on the other hand, though also attaching by cementation and possessing a similar construction with membranous base, has a less expansive basal platform that has sharp marginal edges (Figure 3D) that downcut into the carapace for permanent, entrenched attachment. Attachment by Chelonibia barnacles can leave marks on host scutes that also distinguish the species. Chelonibia testudinaria, which cements superficially to the surface and is facultatively mobile, sometimes leaves behind harmless "skid" marks or traces of trailing adhesive on the surface (Figure 4) while C. caretta, which has a more invasive form of attachment, can leave behind physical indentations or incisions, even cutting entirely through the scutes at times (Figure 5).

In both study sites of mixed turtle species, the barnacle $C$. caretta occurred only on hawksbills. Its incidence was highest in Florida where it was hosted by $82.2 \%$ of hawksbills $(n=275)$ compared to $27.5 \%$ in Madagascar $(n=120)$ (Figure 6). The other species of barnacle, C. testudinaria, in both localities occurred exclusively on green turtles where its percent occurrence on green turtles was $38.1 \%$ in Florida $(n=21)$ compared to $6.3 \%$ in Madagascar $(n=32)$ (Figure 6). The abundance of C. caretta on hawksbills in Madagascar ranged from 0 to 15 barnacles per turtle with an average of $0.98 \pm 0.21$ (SE) (Figure 7A). In Florida, barnacle abundance ranged from 0 to 65 barnacles per hawksbill with an average of $12.01 \pm 0.81$ (SE). The results of the
Welch's two sample $t$-test between the abundance of $C$. caretta on hawksbill carapaces in the two study sites was significantly different $\left(t_{310}=-13.23, p=<0.0001\right)$. The abundance of C. testudinaria on green turtles in Madagascar ranged from 0 to 1 individuals per turtle with an average of $0.08 \pm 0.05$ (SE) barnacles (Figure 7B). In Florida, the range was from 0 to 6 with an average of $0.86 \pm 0.33$ (SE) barnacles. The difference in mean abundance of $C$. testudinaria on green turtle carapaces in the two study sites was not significant $\left(t_{35}=0.29, p=0.77\right)$.

\section{DISCUSSION}

In the mixed stocks of green and hawksbill sea turtles in this study, the epizoic barnacles C. caretta and C. testudinaria exhibited strongly contrasting biases in host occupancy. This follows a general pattern described by Zardus (2021) globally in which both species of barnacles have been reported on both species of turtles, but $C$. caretta is almost always more abundant on hawksbills and infrequent on greens or other sea turtles, while C. testudinaria is common on most other sea turtles but less so on hawksbills.

Though exact drivers remain unknown, differences in host utilization by these barnacle species may be due to preferences at larval settlement, to various post-settlement selection pressures, or some combination of the two. If larvae of these barnacles preferentially select their substratum, this raises the question of what in the surface features or surface environments of 


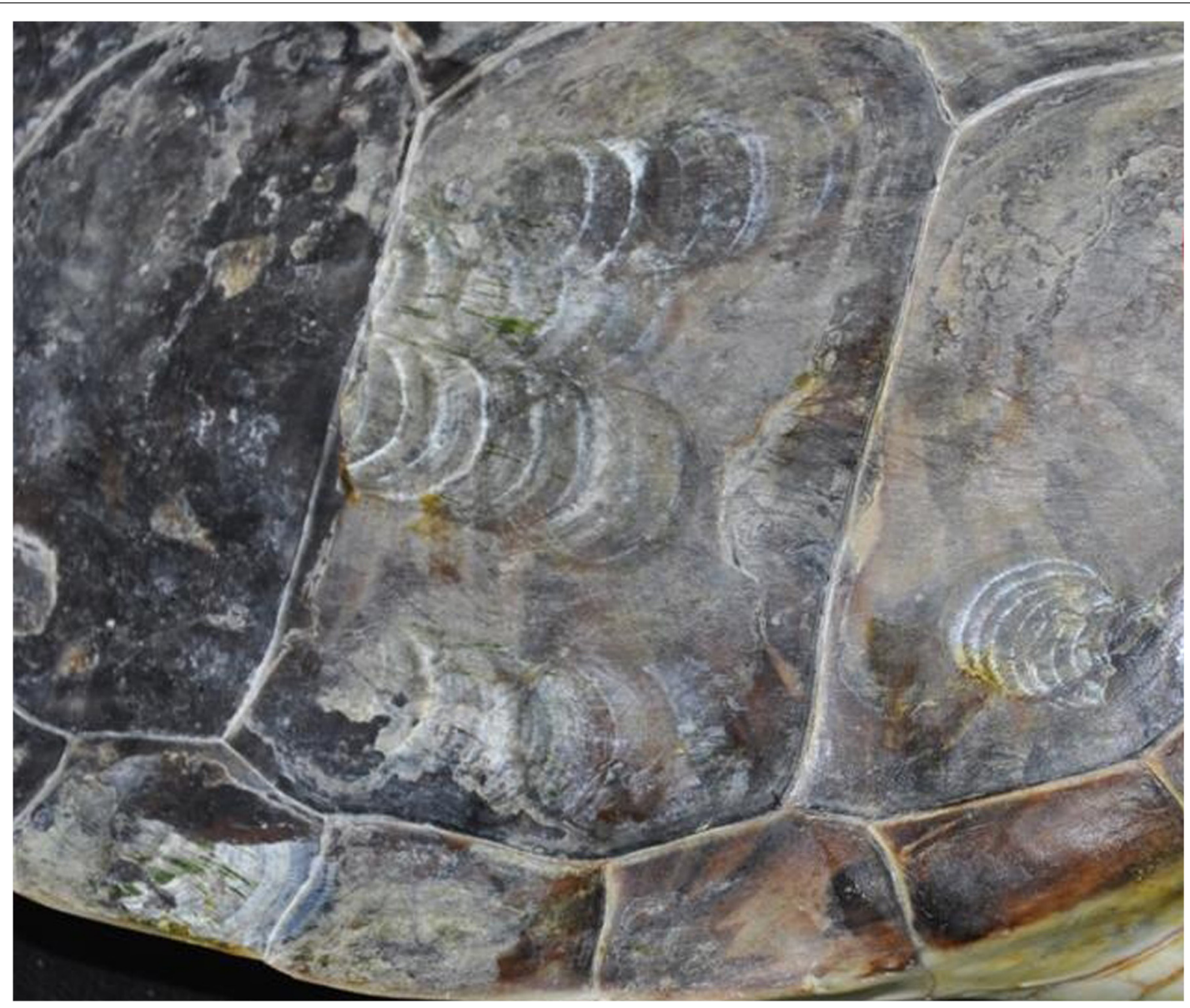

FIGURE 4 | Traces of adhesive cement left by the barnacle Chelonibia testudinaria on the thin carapacial scutes of a green sea turtle, demonstrating the non-destructive attachment and movements of this mobile barnacle (photo made possible by the South Carolina Aquarium, United States).

green and hawksbill turtles differs and what cues do Chelonibia barnacles detect at attachment? Settlement signals for larval barnacles, though intensively studied, are not exhaustively defined. Seemingly tuned less to the material composition of a substratum (Pomerat and Weiss, 1946; Lohse, 1993), barnacles are generally more responsive to physical properties such as texture, hydrophobicity, and surface flow (Crisp, 1955; Wethey, 1986; Mullineaux and Butman, 1991; Di Fino et al., 2014), and especially to chemical cues, either from other attached barnacles (Gabbott and Larman, 1987; Matsumura et al., 1998; Ferrier et al., 2016) or from microbial biofilms (Neal and Yule, 1994; Lau et al., 2005; Dreanno et al., 2006; Bacchetti de Gregoris et al., 2012; Siddik and Satheesh, 2019). It is highly conceivable that Chelonibia barnacles are able to detect and discriminate between hosts chemically. However, host detection by chemoreception in barnacles has rarely been demonstrated and is not known for Chelonibia. In the few studies demonstrating this phenomenon, Pasternak et al. (2004a,b) have confirmed that the cyprids of barnacles commensal with corals and parasitic with crabs can track host chemical plumes in flow and Nogata and Matsumura (2006) have shown that whale-barnacle cyprids successfully metamorphose in petri dishes supplied with bits of whale skin over dishes of plain seawater.
Alternatively for Chelonibia, host selectivity at the larval stage, though certainly operating at least at the level of choosing a turtle, may be subordinate to survivorship at the adult stage. Turtle behavior, where and how they forage, and whether they self-groom or not, may have the greater influence on barnacle distribution patterns. Green turtles are known for actively swiping their carapaces with their flippers and rubbing against reefs and rock ledges to remove epibiota (Parrish, 1958; Limpus, 1980; Heithaus et al., 2002), while hawksbills typically do not engage in such behavior. The lower aspect, domed shell of C. testudinaria, and its temporary, peripatetic attachment may better suit it to host-grooming activities whereas the higher aspect, immobile $C$. caretta may survive better on a non-grooming host. Additionally, post-settlement pressures on barnacle survival may include diet. As suspension feeders, these barnacles may acquire some or much of their nutrition from their hosts' foraging spillover, either obtaining food items from turtles directly or indirectly from material resuspended by host feeding activities. Thus, the diet and/or foraging habitat of each host turtle may differentially influence the sustenance of their barnacle epibionts. Despite these factors, it does seem improbable that post-settlement selection would result in absolute removal of only particular barnacles from both hosts. 


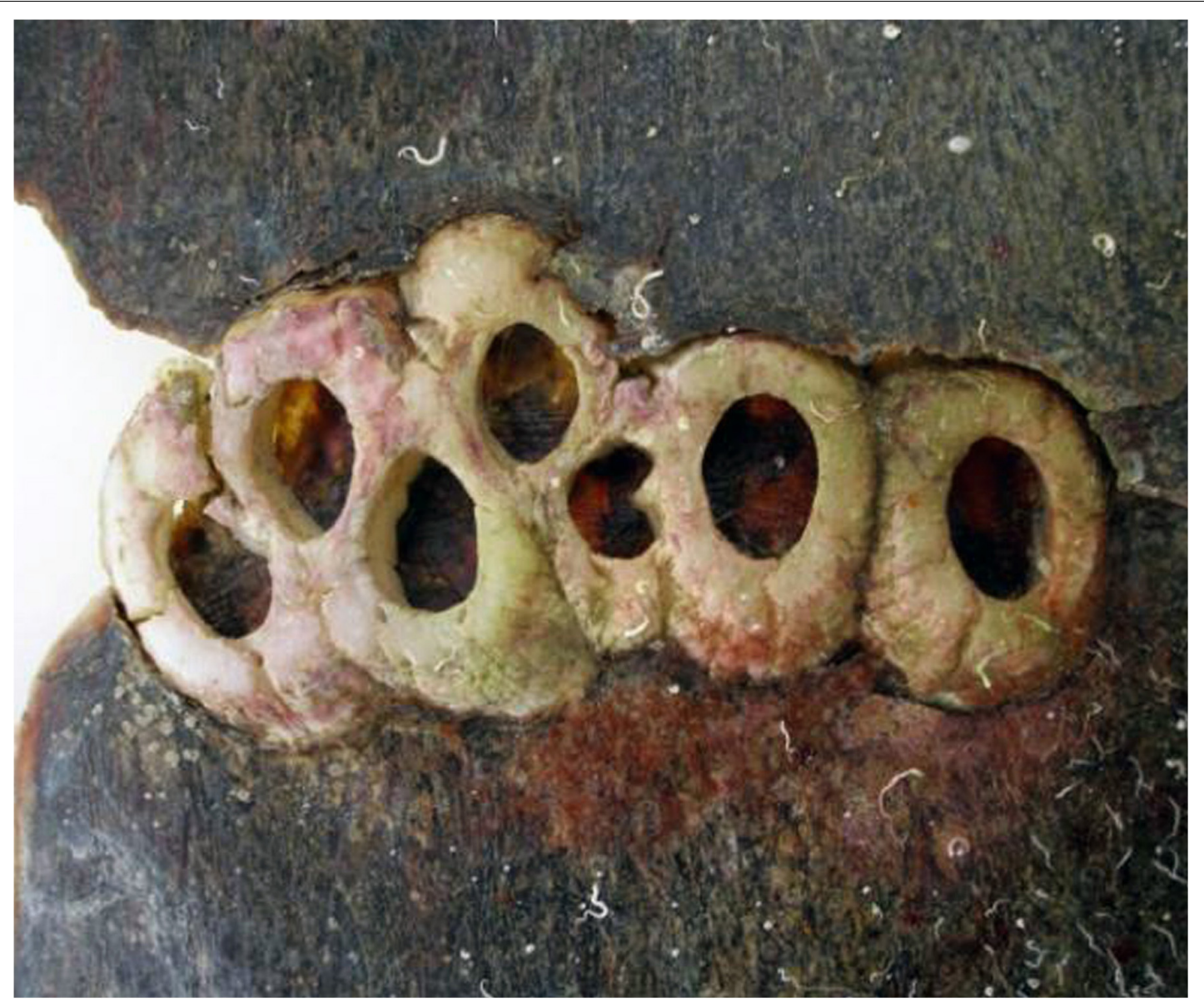

FIGURE 5 | Empty shells of the barnacle Chelonibia caretta entrenched in the thick carapacial scutes of a deceased hawksbill sea turtle, demonstrating the destructive downward cutting action of the barnacle shell margin (photo courtesy of Nicolas Winkler).

Rather, the remarkable, mutually exclusive pattern of barnacle occurrence we observed suggests that larval selectivity is the primary cause of this pattern. Because we did not observe any small barnacles (i.e., recently settled individuals), perhaps due to limitations of photographic analysis, we did not compare patterns relative to barnacle size; which, if such individuals had been present might have provided further insight. Timing of larval development and recruitment for Chelonibia likely varies with latitude but is imprecisely known. In Charleston, South Carolina, United States, latitude $32.8^{\circ} \mathrm{N}$, recruitment has been recorded for C. testudinaria in early spring (Sloan et al., 2014). In tropical locales reproduction may occur year-round but at Mabul Island, Malaysia, $4.3^{\circ} \mathrm{N}$, barnacle size classes for C. testudinaria were larger in May than November, suggesting recruitment periodicity (Lim et al., 2021). Barnacles can also settle on the plastron of turtles (Hayashi and Tsuji, 2008), and in several cases have been found to do so more abundantly there than on the carapace (Ling and Palaniappan, 2011; Razaghian et al., 2019; Loghmannia et al., 2021). But, limited to photographing just the carapace in this study, we were unable to assess occurrence on the entirety of each host which could conceivably alter observed patterns.
If these barnacles are indeed adapted for particular hosts as we suspect, at least in the case of $C$. caretta with hawksbills, regardless of selection occurring either at the larval or adult stage, what advantage does host specificity provide them? The simplest answer is that each is optimized for retaining their attachment on their respective hosts. The thick, enduring scutes of hawksbill turtles and the thinner, deciduous scutes of green and other sea turtles may have been the primary selective agent in shaping the attachment modes of these barnacles. In general, barnacles secrete a very strong adhesive cement (Liang et al., 2019) which makes them suited to turtle shell and keeps them well-secured to their substratum. Thick scutes in hawksbills may have influenced entrenched attachment (and possibly greater longevity) in C. caretta, while intermittent shedding of relatively thin scute layers by green sea turtles may have promoted temporary adhesion and mobility in C. testudinaria. The dynamics and periodicity of scute shedding in sea turtles generally is an understudied aspect of their biology that requires further understanding. Apart from attachment, niche specialization in these barnacles may also be advantageous by reducing interspecific competition for space and food while also improving access for mating. Typically hermaphroditic, 
Percent Chelonibia spp. Presence on Hawksbills and Green Turtles

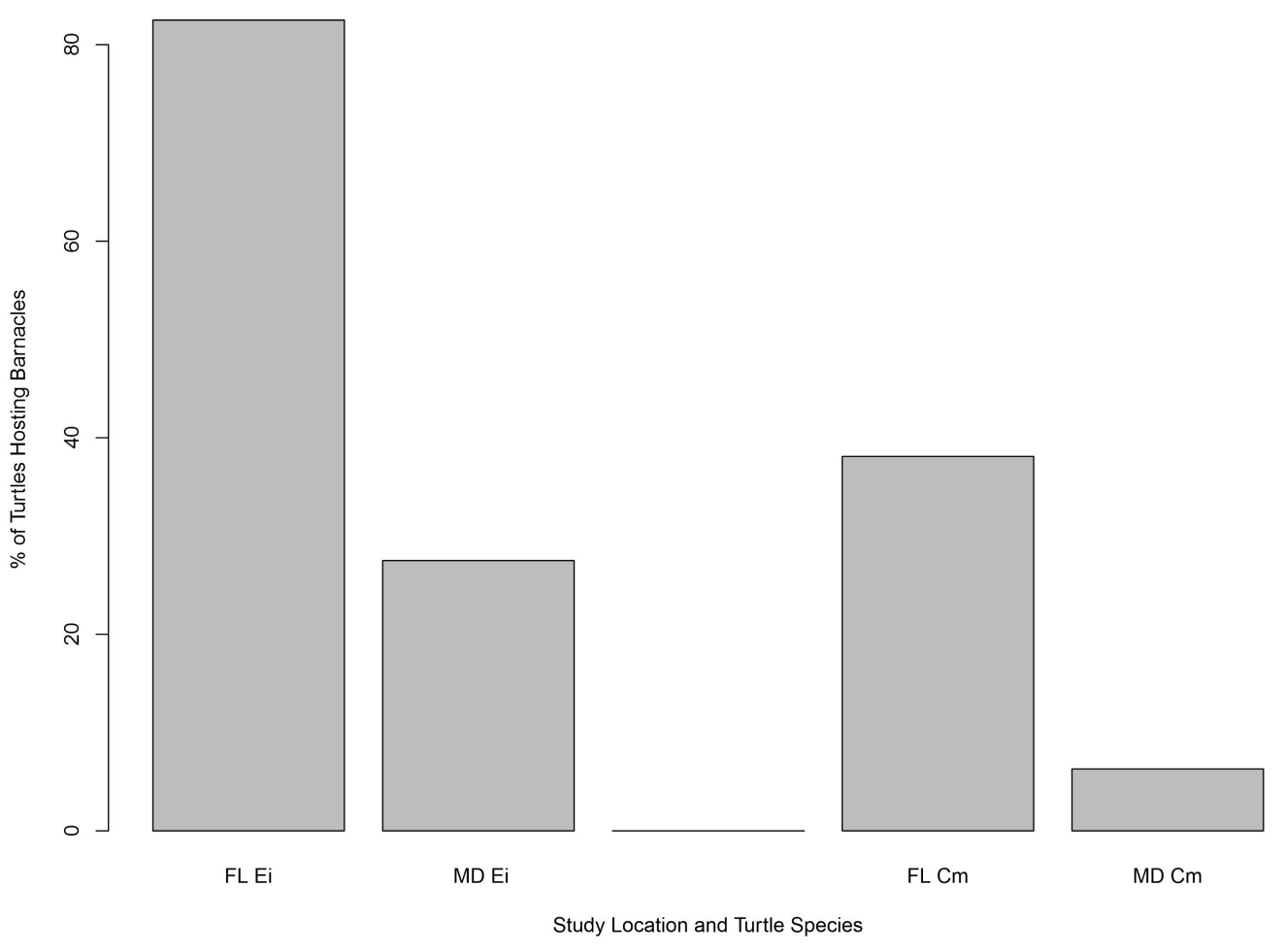

FIGURE 6 | Percent occurrence of Chelonibia barnacles per host species per geographic location, for hawksbill (Ei) and green turtles (Cm) in Florida (FL) and Madagascar (MD). At both locations, hawksbill turtles hosted the barnacle C. caretta only and green turtles only C. testudinaria.

acorn barnacles are not self-fertile and must cross-copulate with neighboring individuals for reproduction (Anderson, 1994). Eliminating other species as a physical barrier could increase chances for mating. Surprisingly, the species with mobility, C. testudinaria, has the most versatile mating system comprised of tiny complemental males, sometimes many in number, that attach to and ride around with larger hermaphrodites (Zardus and Hadfield, 2004). Chelonibia caretta on the other hand is not known for complemental males, but we have observed it is more commonly found in aggregations of multiple hermaphrodites with shell plates fused together.

For future investigation, it would be valuable to know how feeding and growth vary between these species of barnacles. Chelonibia caretta does not become as large as C. testudinaria and perhaps entrenched attachment is a factor that limits its size. Not growing as wide as C. testudinaria either, it does, however, grow as tall or taller. Along these lines, it would be interesting to know how it expands its base while also growing entrenched. Life expectancies may also vary between these species. Chelonibia testudinaria lives approximately 2 years (Doell et al., 2017) but ages for $C$. caretta are not known, yet by being a hawksbill specialist, $C$. caretta may have a significantly longer lifespan and perhaps slower growth rate than its congener. In addition to growth, identifying the reproductive period of each species in areas where they co-occur would help in knowing if their larval stages develop simultaneously. Even better would be to identify their larval distribution in the plankton, perhaps by molecular genetic methods (Chen et al., 2013).

Investigating epibiont occurrence within co-occurring populations of multiple turtle species is a valuable but uncommon approach to understanding selectivity of epibionts (Robinson et al., 2017). Examining larger spatial scopes and different assemblages of hosts would help provide a more complete perspective of barnacle epibiosis of marine turtles. Expanding the area of study beyond exclusively the carapace would provide a more holistic understanding of barnacle settlement on sea turtle individuals. Indeed, differences in settlement abundance on the carapace, plastron and facial scales has been documented for barnacles on some turtles (Hayashi and Tsuji, 2008; Ling and Palaniappan, 2011; Razaghian et al., 2019; Chan et al., 2021; Loghmannia et al., 2021), though the meaning of these patterns remains elusive. Loggerhead sea turtles are another species known to host a diverse array of marine epibionts, including $C$. testudinaria and C. caretta (Caine, 1986; Zardus, 2021). Cross comparisons of barnacle assemblages in sites where green, loggerhead, and hawksbills are all present would be a valuable contribution. But settlement choice experiments in the laboratory would address the question of larval selectivity more directly and potentially provide the most definitive answers.

Because larval distribution of these epizoic barnacles is presumably limited to the ranges and source populations of 
A

Hawksbill Chelonibia caretta Abundance

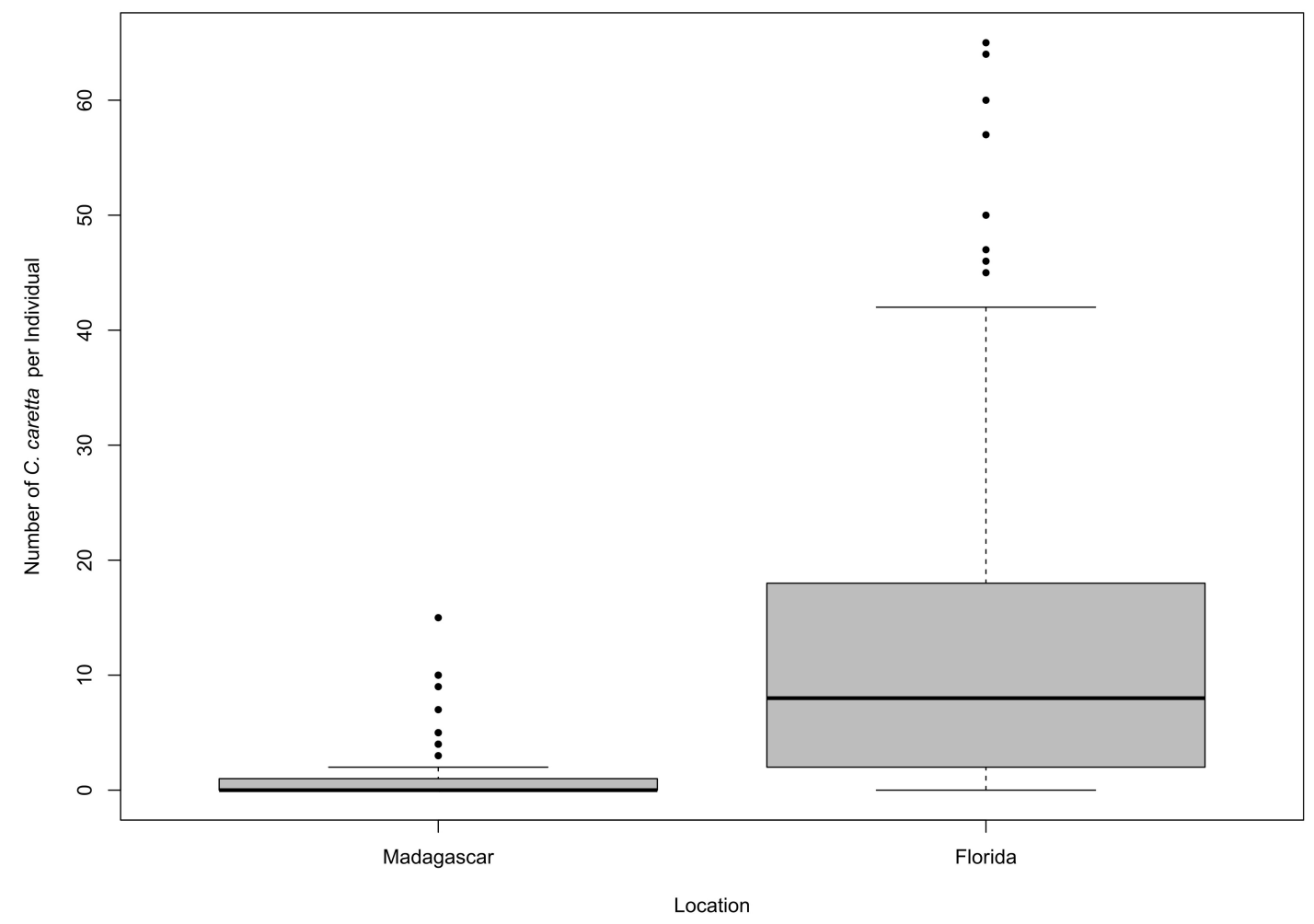

B

Green Turtle Chelonibia testudinaria Abundance

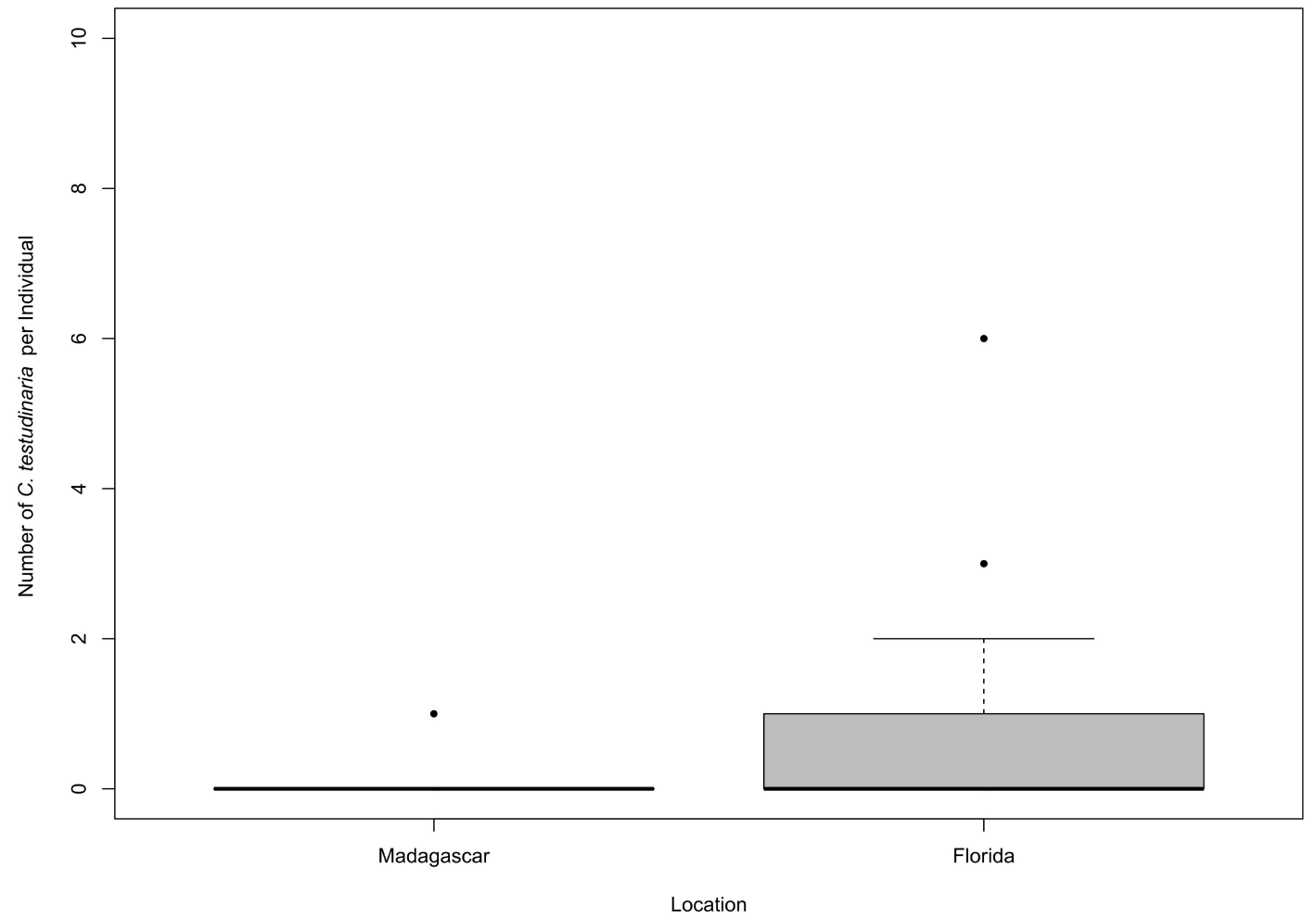

FIGURE 7| Quantity of respective barnacles present on (A) hawksbill and (B) green turtles in Madagascar and Florida. 
their sea turtle hosts, declines of hawksbill and green sea turtles may be of consequence to them, particularly C. caretta whose hawksbill host populations have diminished by over 80 percent over the last several hundred years (Mortimer and Donnelly, 2008). Chelonibia testudinaria, which associates with all sea turtle species (Zardus, 2021) and even some non-turtle hosts (Zardus et al., 2014), has greater substratum choice and widespread occurrence and may be at less peril. Intra-oceanic host migrations undoubtedly assist in genetically diversifying their associated epibiota across widely dispersed populations, and further understanding the degree of population connectivity of the epibionts of sea turtles is crucial to evaluating their conservation status.

\section{DATA AVAILABILITY STATEMENT}

The raw data supporting the conclusions of this article will be made available by the authors, without undue reservation.

\section{ETHICS STATEMENT}

The animal study was reviewed and approved by the Institutional Animal Care and Use Committee, Florida International University Office of Research Integrity.

\section{AUTHOR CONTRIBUTIONS}

$\mathrm{LB}, \mathrm{JZ}$, and LW contributed to the original concept and design of the study. LB, CK, and LW collected data from the field. LB conducted the data analysis and led the manuscript. All authors wrote and edited the manuscript.

\section{FUNDING}

Work conducted in Madagascar by LB and CK was supported by funds from multiple travel and research awards from the

\section{REFERENCES}

Anderson, D. T. (1994). Barnacles: Structure, Function, Development and Evolution. London: Chapman and Hall.

Bacchetti de Gregoris, T., Khandeparker, L., Anil, A. C., Mesbahi, E., Burgess, J. G., and Clare, A. S. (2012). Characterisation of the bacteria associated with barnacle, Balanus amphitrite, shell and their role in gregarious settlement of cypris larvae. J. Exp. Mar. Biol. Ecolo. 413, 7-12. doi: 10.1016/j.jembe.2011.1 1.014

Banks, K. W., Riegl, B. M., Richards, V. P., Walker, B. K., Helmle, K. P., Jordan, L. K. B., et al. (2008). "The reef tract of continental southeast Florida (miamidade, broward and palm beach counties, USA)," in Coral Reefs of the USA, eds B. M. Riegl and R. E. Dodge (Dordrecht, Netherlands: Springer), 175-220. doi: 10.1007/978-1-4020-6847-8_5

Bechhofer, J., and Henderson, A. C. (2018). Transient nocturnal site fidelity in juvenile green (Chelonia mydas) and hawksbill (Eretmochelys imbricata) sea turtles on the shallow nearshore coral reefs of South Caicos, Turks and Caicos Islands. Trop. Zool. 31, 44-54. doi: 10.1080/03946975.2017.1403196

Berube, M. D., Dunbar, S. G., Rützler, K., and Hayes, W. K. (2012). Home range and foraging ecology of juvenile hawksbill sea turtles (Eretmochelys imbricata)
Tropical Conservation Institute and the Coastlines and Oceans Division in the Institute of Environment at Florida International University, the Judith Evans Parker Travel Scholarship, the PADI Foundation, Happy Earth Apparel, and National Science Foundation Grant No. \#1827195 (awarded to M. Heithaus, J. Kiszka, and C. Gomes). Funding was provided by the National Save the Sea Turtle Foundation for all work conducted in Florida by $\mathrm{LB}, \mathrm{CK}$, and LW.

\section{ACKNOWLEDGMENTS}

We would like to thank the Florida Hawksbill Project at the National Save the Sea Turtle Foundation and Inwater Research Group, Inc., for providing the photographs of Florida hawksbill and green turtles for this study. Activities in Florida were authorized under the following research permits: NMFS 22988, FWC MTP-077, and FKNMS-2019-175. We would like to thank Tanikely Marine Park, Madagascar National Parks, Institut Halieutique et des Sciences Marines, particularly Dr. Jamal Mahafina, the Ministère de l'Environnement, the Ministère de l'Enseignement Supérieur et de la Recherche and the Direction de la Gestion des Ressources Naturelles Renouvelables et des Ecosystèmes (ref no. 126/19/MEDD/DGEF/DGRNE) for permission to conduct studies on Madagascar green and hawksbill turtles. The authors are grateful to the Director of Tanikely Marine Park, Landisoa Randimbison, to Salama Doholo at the Ministère de l'Environnement, Pat Wright, and Elina Sourisseau, Tanguy Guillemain d'Echon, Arthur Guillemain d'Echon, and Mathieu Le Peru from MADA Megafauna, for their support during our time in the field. Work in Madagascar would not have been possible without the aid of our field assistants: Monica Soamanjary, Cristian, Jeanne Beuscart, Mylène Richard, and Zachary Howard. We are extremely appreciative of the support from all of our funders and the guidance from both Michael Heithaus and Jeremy Kiszka at Florida International University. This is publication \#1413 of the Coastlines and Oceans Division of the Institute of Environment.

on inshore reefs of Honduras. Chelonian Conserv. Biol. 11, 33-43. doi: 10.2744/ CCB-0898.1

Bjorndal, K. A., and Bolten, A. B. (2010). Hawksbill turtles in seagrass pastures: success in a peripheral habitat. Mar. Biol. 157, 135-145. doi: 10.1007/s00227009-1304-0

Booth, J., and Peters, J. A. (1972). Behavioural studies on the green turtle (Chelonia mydas) in the sea. Animal Behav. 20, 808-812. doi: 10.1016/S0003-3472(72) 80155-6

Bourjea, J., Ciccione, S., and Ratsimbazafy, R. (2006). Marine turtles surveys in Nosy Iranja Kely, north-western madagascar. Western Indian Ocean J. Mar. Sci. 5, 209-212. doi: 10.4314/wiojms.v5i2.28511

Caine, E. A. (1986). Carapace epibionts of nesting loggerhead sea turtles: Atlantic coast of USA. J. Exp. Mar. Biol. Ecol. 95, 15-26. doi: 10.1016/0022-0981(86) 90084-5

Chan, B. K. K., Wong, Y. H., Robinson, N. J., Lin, J.-C., Yu, S.-P., Dreyer, N., et al. (2021). 500 million years to mobility: directed locomotion and its ecological function in a turtle barnacle. Proc. R. Soc. B 288:20211620. doi: 10.1098/rspb. 2021.1620

Cheang, C. C., Tsang, L. M., Chu, K. H., Cheng, I.-J., and Chan, B. K. K. (2013). Host-specific phenotypic plasticity of the turtle barnacle Chelonibia 
testudinaria: a widespread generalist rather than a specialist. PLoS One 8:e57592. doi: 10.1371/journal.pone.0057592

Chen, H.-N., Høeg, J. T., and Chan, B. K. K. (2013). Morphometric and molecular identification of individual barnacle cyprids from wild plankton: an approach to detecting fouling and invasive barnacle species. Biofouling 29, 133-145. doi: 10.1080/08927014.2012.753061

Collareta, A., and Newman, W. A. (2020). Protochelonibia melleni (Zullo, 1982) comb. nov., an archaic barnacle from the lower oligocene of mississippi (USA), and its impact on the stratigraphic and geographic distribution of the early coronuloids of western tethys. Bollettino della Società Paleontol. Italiana 59, 179-181. doi: 10.4435/BSPI.2020.08

Collareta, A., Newman, W. A., Bosio, G., and Coletti, G. (2021). A new chelonibiid from the Miocene of Zanzibar (Eastern Africa) sheds light on the evolution of shell architecture in turtle and whale barnacles (cirripedia: coronuloidea). Integrative Zool. 00, 1-20. doi: 10.1111/1749-4877.12554

Crisp, D. J. (1955). The behaviour of barnacle cyprids in relation to water movement over a surface. J. Exp. Biol. 32, 569-590.

Di Fino, A., Petrone, L., Aldred, N., Ederth, T., Liedberg, B., and Clare, A. S. (2014). Correlation between surface chemistry and settlement behaviour in barnacle cyprids (Balanus improvisus). Biofilms 30, 143-152. doi: 10.1080/08927014. 2013.852541

Doell, S. A., Connolly, R. M., Limpus, C. J., Pearson, R. M., and Van De Merwe, J. P. (2017). Using growth rates to estimate age of the sea turtle barnacle Chelonibia testudinaria. Mar. Biol. 164, 1-7. doi: 10.1007/s00227-017-3251-5

Dreanno, C., Kirby, R. R., and Clare, A. S. (2006). Locating the barnacle settlement pheromone: spatial and ontogenetic expression of the settlement-inducing protein complex of Balanus amphitrite. Proc. R. Soc. B Biol. Sci. 273, 2721-2728. doi: $10.1098 /$ rspb.2006.3649

Dreyer, N., Zardus, J. D., Høeg, J. T., Olesen, J. M., Yu, M.-C., and Chan, B. K. K. (2020). How dolphin barnacles attach to their hosts and the paradox of remarkably versatile attachment structures in cypris larvae. Organ. Div. Evolu. 20, 233-249. doi: 10.1007/s13127-020-00434-3

Ewers-Saucedo, C., Chan, B. K. K., Zardus, J. D., and Wares, J. P. (2017). Parallel patterns of host-specific morphology and genetic admixture in sister lineages of a commensal barnacle. Biol. Bull. 232, 171-185. doi: 10.1086/693356

Ferrier, G. A., Kim, S. J., Kaddis, C. S., Loo, J. A., Zimmer, C. A., and Zimmer, R. K. (2016). MULTIFUNCin: a multifunctional protein cue induces habitat selection by, and predation on, barnacles. Integrative Comparative Biol. 56, 901-913. doi: 10.1093/icb/icw076

Foster, B. A. (1987). "Barnacle ecology and adaptation," in Barnacle Biology, ed. A. J. Southward (Rotterdam, NL), 113-134. doi: 10.1201/9781315138053

Frazier, J. G., Goodbody, I., and Ruckdeschel, C. A. (1991). Epizoan communities on marine turtles: II. tunicates. Bull. Mar. Sci. 48, 763-765.

Frick, M. G., Williams, K. L., Markesteyn, E. J., Pfaller, J. B., and Frick, R. E. (2004). New records and observations of epibionts from loggerhead sea turtles. Southeastern Natur. 3, 613-620.

Gabbott, P. A., and Larman, V. N. (1987). "The chemical basis of gregariousness in cirripedes: a review (1953-1984)," in Barnacle Biology, ed. A. J. Southward (Rotterdam, NL), 377-388.

Grossman, A., Sazima, C., Bellini, C., and Sazima, I. (2006). Cleaning symbiosis between hawksbill turtles and reef fishes at Fernando de Noronha Archipelago, off Northeast Brazil. Chelonian Conserv. Biol. 5, 284-288.

Hayashi, R., and Tsuji, K. (2008). Spatial distribution of turtle barnacles on the green sea turtle, Chelonia mydas. Ecol. Res. 23, 121-125. doi: 10.1007/s11284007-0349-0

Hazel, J., Hamann, M., and Lawler, I. R. (2013). Home range of immature green turtles tracked at an offshore tropical reef using automated passive acoustic technology. Mar. Biol. 160, 617-627. doi: 10.1007/s00227-012-2117-0

Heithaus, M. R., McLash, J. J., Frid, A., Dill, L. M., and Marshall, G. J. (2002). Novel insights into green sea turtle behaviour using animal-borne video cameras. J. Mar. Biol. Assoc. U.K. 82, 1049-1050. doi: 10.1017/S0025315402006689

Jaap, W. C., and Hallock, P. (1990). “Coral reefs," in Ecosystems of Florida, eds R. L. Myers and J. J. Ewel (Orlando, Florida: University of Central Florida Press), 574-616.

Lane, Z. M., Mcelroy, E. J., Kendrick, M. R., and Zardus, J. D. (2021). Experimental demonstration of exclusively passive feeding in the sea-turtle barnacle Chelonibia testudinaria (Linnaeus, 1758) (cirripedia: coronulidae). J. Crust. Biol. 41:ruab053. doi: 10.1093/jcbiol/ruab053
Lau, S. C. K., Thiyagarajan, V., Cheung, S. C. K., and Qian, P.-Y. (2005). Roles of bacterial community composition in biofilms as a mediator for larval settlement of three marine invertebrates. Aquat. Microbial Ecol. 38, 41-51. doi: 10.3354/ ame038041

Liang, C., Strickland, J., Ye, Z., Wu, W., Hu, B., and Rittschof, D. (2019). Biochemistry of barnacle adhesion: an updated review. Front. Mar. Sci. 6:565. doi: $10.3389 /$ fmars.2019.00565

Lim, K. K., Hussein, M. A. S., and Palaniappan, P. M. (2021). Abundance, placement and sexual identity of the epizoic barnacle Chelonibia testudinaria relative to the size and species of host turtles in Mabul Island, Malaysia. J. Mar. Biol. Assoc. U.K. 100, 1299-1309. doi: 10.1017/S0025315420001198

Limpus, C. J. (1980). The green turtle, Chelonia mydas (L.) in eastern Australia. Manage. Turtle Resour. Res. Monogr. 1, 5-22.

Ling, O. S., and Palaniappan, P. M. (2011). Silent turtle dwellers: barnacles on resident green and hawksbill turtles of Mabul and Sipadan Islands. Borneo Sci. 28, 66-72.

Loghmannia, J., Nasrolahi, A., Rezaie-Atagholipour, M., and Kiabi, B. H. (2021). Epibiont assemblages on nesting hawksbill turtles show site-specificity in the Persian Gulf. Front. Ecol. Evol. 9:690022. doi: 10.3389/fevo

Lohse, D. P. (1993). The effects of substratum type on the population dynamics of three common intertidal animals. J. Exp. Mar. Biol. Ecol. 173, 133-154. doi: 10.1016/0022-0981(93)90212-7

Losey, G. S. Jr., Balazs, G. H., and Privitera, L. A. (1994). Cleaning symbiosis between the wrasse, thalassoma duperry, and the green turtle, Chelonia mydas. Copeia 3, 684-690. doi: 10.2307/1447184

Makowski, C., Seminoff, J. A., and Salmon, M. (2006). Home range and habitat use of juvenile Atlantic green turtles (Chelonia mydas L.) on shallow reef habitats in Palm Beach, Florida, USA. Mar. Biol. 148, 1167-1179. doi: 10.1007/s00227005-0150-y

Matsumura, K., Nagano, M., and Fusetani, N. (1998). Purification of a settlementinducing protein complex (SIPC) of the barnacle, Balanus amphitrite. J. Exp. Zool. 281, 12-20. doi: 10.1002/(SICI)1097-010X(19980501)281:1

McKenna, S. A., and Allen, G. R. (2003). A Rapid Marine Biodiversity Assessment of Northwest Madagascar. Bulletin of the Rapid Assessment Program, 31. Washington, D.C: Conservation International.

Monroe, R. (1981). Studies in the coronulidae (cirripedia): shell morphology, growth, and function, and their bearing on subfamily classification. Memoirs Queens. Museum 20, 237-251.

Monroe, R., and Garrett, R. (1979). Chelonibia testudinaria (L.)(cirripedia, coronulidae) on Crocodylus porosus schneider, a new host record. Crustaceana 36:108.

Moriarity, J. E., Sachs, J. A., and Jones, K. (2008). Directional locomotion in a turtle barnacle, Chelonibia testudinaria, on green turtles, Chelonia mydas. Mar. Turtle News. 119, 1-3.

Mortimer, J. A., and Donnelly, M. (2008). Eretmochelys Imbricata. The IUCN Red List of Threatened Species 2008: e.T8005A12881238. IUCN SSC Marine Turtle Specialist Group.

Mrosovsky, N. (2000). Sustainable Use of Hawksbill Turtles: Contemporary Issues in Conservation. Darwin, Australia: Key Centre for Tropical Wildlife Management.

Mullineaux, L. S., and Butman, C. A. (1991). Initial contact, exploration and attachment of barnacle (Balanus amphitrite) cyprids settling in flow. Mar. Biol. 110, 93-103. doi: 10.1007/BF01313096

Neal, A. L., and Yule, A. B. (1994). The tenacity of Elminius modestus and Balanus perforatus cyprids to bacterial films grown under different shear regimes. J. Mar. Biol. Assoc. U.K. 74, 251-257. doi: 10.1017/S0025315400035815

Nifong, J. C., and Frick, M. G. (2011). First record of the American alligator (Alligator mississippiensis) as a host to the sea turtle barnacle (Chelonibia testudinaria). Southeastern Natur. 10, 557-560. doi: 10.1656/058.010.0316

Nogata, Y., and Matsumura, K. (2006). Larval development and settlement of a whale barnacle. Biol. Lett. 2, 92-93. doi: 10.1098/rsbl.2005.0409

Obura, D. (2012). The diversity and biogeography of Western Indian Ocean reef-building corals. PLoS One 7:e45013. doi: 10.1371/journal.pone. 0045013

Obura, D., Gudka, M., Rabi, F. A., Gian, S. B., Bijoux, J., Freed, S., et al. (2017). Coral Reef Status Report for the Western Indian Ocean. Global Coral Reef Monitoring Network (GCRMN)/International Coral Reef Initiative (ICRI). Nairobi: Nairobi Convention. 
Ortiz, M., Lalana, R., and Varela, C. (2004). Caso extremo de epibiosis de escaramujos (cirripedia: balanomorpha), sobre una esquila (hoplocarida: stomatopoda), en cuba. Revista de Invest. Mar. 25, 75-76.

Palaniappan, P. M. (2007). The Carapacial Scutes of Hawksbill Turtles (Eretmochelys imbricata): Development, Growth Dynamics and Utility as an Age Indicator Ph. $D$, Thesis. Darwin: Charles Darwin University.

Parrish, F. K. (1958). Miscellaneous observations on the behavior of captive sea turtles. Bull. Mar. Sci. Gulf Caribbean 8, 348-355.

Pasternak, Z., Blasius, B., and Abelson, A. (2004a). Host location by larvae of a parasitic barnacle: larval chemotaxis and plume tracking in flow. J. Plankton Res. 26, 487-493. doi: 10.1093/plankt/fbh040

Pasternak, Z., Blasius, B., Achituv, Y., and Abelson, A. (2004b). Host location in flow by larvae of the symbiotic barnacle Trevathana dentata using odourgated rheotaxis. Proc. R. Soc. London B 271, 1745-1750. doi: 10.1098/rspb.2004. 2765

Pederson, M. C. (2021). Tortoiseshell. Wiltshire, UK: NAG Press.

Pomerat, C. M., and Weiss, C. M. (1946). The influence of texture and composition of surface on the attachment of sedentary marine organisms. Biol. Bull. 91, 57-65. doi: 10.2307/1538033

Rawson, P. D., Macnamee, R., Frick, M. G., and Williams, K. L. (2003). Phylogeography of the coronulid barnacle, Chelonibia testudinaria, from loggerhead sea turtles, caretta. Mol. Ecol. 12, 2697-2706. doi: 10.1046/j.1365294X.2003.01940.x

Razaghian, H., Esfandabad, B. S., Hesni, M. A., Shoushtari, R. V., Toranjzar, H., and Miller, J. (2019). Distribution patterns of epibiotic barnacles on the Hawksbill turtle, Eretmochelys imbricata, nesting in Iran. Regional Stud. Mar. Sci. 27, 1-6. doi: 10.1016/j.rsma.2019.100527

Robinson, J. J., Lazo-Wasem, E. A., Paladino, F. A., Zardus, J. D., and Pinou, T. (2017). Assortative epibiosis of leatherback, olive ridley and green sea turtles in the eastern tropical pacific. J. Mar. Biol. Assoc. U.K. 97, 1233-1240. doi: $10.1017 /$ S0025315416000734

Ross, A. (1963). Chelonibia in the neogene of florida. Quart. J. Florida Acad. Sci. 26, 221-233.

Sagar, J. P. (2001). Ecology and Conservation of Sea Turtles in the Nosy Be Islands, Madagascar. Madagascar: Unpublished Report, WWF.

Sazima, C., Grossman, A., and Sazima, I. (2010). Turtle cleaners: reef fishes foraging on epibionts of sea turtles in the tropical southwestern Atlantic, with a summary of this association type. Neotrop. Ichthyol. 8, 187-192. doi: 10.1590/S167962252010005000003

Scharer, M. T. (2001). A survey of the epibiota of Eretmochlys imbricata (testudines:cheloniidae) of Mona Island Puerto rico. Revista de Biologia Trop. 51, 87-90.

Seigel, R. A. (1983). Occurrence and effects of barnacle infestations on diamondback terrapins (Malaclemys terrapin). Am. Midland Natur. 109, 34-39.

Seminoff, J. A. (2004). Chelonia Mydas. The IUCN Red List of Threatened Species 2004. Cambridge: International Union for Conservation of Nature and Natural Resources. doi: 10.2305/IUCN.UK.2004.RLTS.T4615A1103 7468.en

Siddik, A., and Satheesh, S. (2019). Characterization and assessment of barnacle larval settlement-inducing activity of extracellular polymeric substances isolated from marine biofilm bacteria. Sci. Rep. 9:17849. doi: 10.1038/s41598019-54294-9

Sloan, K., Zardus, J. D., and Jones, M. L. (2014). Substratum fidelity and early growth in Chelonibia testudinaria, a turtle barnacle especially common on debilitated loggerhead (caretta caretta) sea turtles. Bull. Mar. Sci. 90, 581-597. doi: 10.5343/bms.2013.1033

Taquet, C., Taquet, M., Dempster, T., Soria, M., Ciccione, S., Roos, D., et al. (2006). Foraging of the green sea turtle Chelonia mydas on seagrass beds at Mayotte Island (Indian Ocean), determined by acoustic transmitters. Mar. Ecol. Prog. Ser. 306, 295-302. doi: 10.3354/meps306295

Webster, F. J., and McMahon, K. (2002). An assessment of coral reefs in northwest Madagascar. Stockholm: Cordio.

Wethey, D. S. (1986). Ranking of settlement cues by barnacle larvae: influence of surface contour. Bull. Mar. Sci. 39, 393-400.

Wood, L. D., Brunnick, B., and Milton, S. L. (2017). Home range and movement patterns of subadult hawksbill sea turtles in Southeast Florida. J. Herpetol. 51, 58-67. doi: 10.1670/15-133

Wood, L. D., Hardy, R., Meylan, P. A., and Meylan, A. B. (2013). Characterization of a hawksbill turtle (Eretmochelys imbricata) foraging aggregation in a highlatitude reef community in southeastern Florida, USA. Herpetol. Conserv. Biol. 8, 258-275.

Wyneken, J. (1996). "Sea turtle locomotion: mechanisms, behavior, and energetics," in The Biology of Sea Turtles, eds M. J. Kennish and P. L. Lutz (CRC Press), 165-198.

Zardus, J. D. (2021). A global synthesis of the correspondence between epizoic barnacles and their sea turtle hosts. Integrative Organ. Biol. 3:obab002. doi: 10.1093/iob/obab018

Zardus, J. D., and Hadfield, M. G. (2004). Larval development and complemental males in Chelonibia testudinaria, a barnacle commensal with sea turtles. J. Crustacean Biol. 24, 409-421. doi: 10.1651/C-2476

Zardus, J. D., Lake, D. T., Frick, M. G., and Rawson, P. D. (2014). Deconstructing an assemblage of "turtle" barnacles: species assignments and fickle fidelity in Chelonibia. Mar. Biol. 161, 45-59. doi: 10.1007/s00227-013-2312-7

Conflict of Interest: The authors declare that the research was conducted in the absence of any commercial or financial relationships that could be construed as a potential conflict of interest.

Publisher's Note: All claims expressed in this article are solely those of the authors and do not necessarily represent those of their affiliated organizations, or those of the publisher, the editors and the reviewers. Any product that may be evaluated in this article, or claim that may be made by its manufacturer, is not guaranteed or endorsed by the publisher.

Copyright (c) 2021 Boyd, Zardus, Knauer and Wood. This is an open-access article distributed under the terms of the Creative Commons Attribution License (CC BY). The use, distribution or reproduction in other forums is permitted, provided the original author(s) and the copyright owner(s) are credited and that the original publication in this journal is cited, in accordance with accepted academic practice. No use, distribution or reproduction is permitted which does not comply with these terms. 